\title{
Sinkronisasi Estrus Sapi Peranakan Ongole Di Kelompok Tani Sri Mulyo
}

\author{
Sigit Prastowo", Sunarto, Lutojo, Nuzul Widyas, Adi Ratriyanto \\ Program Studi Peternakan, Fakultas Pertanian, Universitas Sebelas Maret, Surakarta \\ *Corresponding Author : prastowo@staff.uns.ac.id
}

\begin{abstract}
ABSTRAK
Kelompok Tani Sri Mulyo merupakan kelompok peternak sapi Peranakan Ongole (PO) yang menghadapi kendala untuk meningkatkan angka kebuntingan. Permasalahan yang dihadapi adalah kejadian estrus / birahi tenang sehingga penentuan waktu Inseminasi Buatan (IB) tidak tepat dan kemudian berakibat pada kegagalan kebuntingan. Salah satu upaya untuk mengatasi hal tersebut, dilakukan program pengabdian kepada masyarakat dengan mengaplikasikan metode sinkronisasi estrus (SE) agar tampilan estrus mudah diamati. Pengabdian ini dilakukan dalam 3 tahap, yaitu sosialisasi, pelaksanaan dan evaluasi. Informasi dan kesepakatan tentang program SE disosialisasikan pada tahap pertama, dilanjutkan dengan pelaksanaan di lapangan. Sebanyak 20 ekor sapi PO digunakan dalam program ini dan dari hasil pemeriksaan organ reproduksi diperoleh sebanyak 12 ekor sapi layak untuk disinkronisasi estrus. Hormon yang digunakan dalam program SE ini adalah PGF2 $\alpha$ dengan metode dua kali injeksi. Hasil SE didapatkan 10 ekor sapi teramati estrus, sedangkan 2 ekor terlewatkan pengamatannya. Inseminasi dengan semen beku kemudian dilakukan dan dievaluasi keberhasilannya setelah 21 dan 60 hari. Sebanyak 6 ekor tidak menunjukkan tandatanda estrus pada hari ke 21 setelah IB, dan 4 ekor dinyatakan bunting setelah evaluasi dengan palpasi rektal pada hari ke 60. Selanjutnya, kelahiran pedet didapatkan sebanyak 4 ekor. Berdasar hasil program SE dapat disimpulkan bahwa penggunaan program SE dapat meningkatkan jumlah sapi betina bunting di Kelompok Tani Sri Mulyo.
\end{abstract}

Kata kunci : PGF2 $\alpha$, Sapi PO, Sinkronisasi Estrus,

\begin{abstract}
Farmer Community named Sri Mulyo is a group of farmer which run Ongole Grade cattle bussines aside from their agriculture farming. There is exist an obstracle in improving their cattle pregnancy rate due to silent heat which lead to fail of best insemination time. To overcome this problem, estrous synchronization was applied, as community service program, in 3 steps namely socialization, implementation and evaluation. At the socialization step, farmer community members were informed about the program, followed with field implementation. In total 20 head of cow used and evaluated its eligibility. As the result, we found 12 head of cow were eligible to be sychonized using PGF2 $\alpha$ double injection. The estrous observation showed 10 cows were in heat and the remaining were missed to evaluate. Following estrous, cows were inseminated using frozen semen, and pregnancy test or evaluation was performed within next 21 and 60 days. Six cows were not showing estrous signs at day 21, among them 4 heads were comfirmed to be pregnant at day 60 by rectal palpation, and finally 4 calves were delivered. According to the result, it is concluded that the application of estrous synchronization program shows improvement number of pregnant cows in Sri Mulyo farmer comunity.
\end{abstract}

Keywords : Estrous Synchronization, Ongole Grade Cattle, PGF2 $\alpha$

\section{PENDAHULUAN}

Sapi Peranakan Ongole (PO) adalah sapi yang banyak diusahakan oleh peternakan rakyat, terutama di Jawa Tengah (Kusuma et al., 2017).
Sapi ini merupakan tipe dwiguna yaitu untuk produksi daging dan pekerja (Hartati et al., 2010). Sapi PO memiliki kemampuan adaptasi yang tinggi terhadap kondisi lingkungan tropis dan pakan kualitas rendah, oleh karena itu, cocok 
dengan karakteristik peternakan rakyat di Indonesia. Terkait pengembangan sapi PO yang merupakan bagian dari populasi sapi lokal, terjadi kecenderungan penurunan populasi (Astuti, 2004) yang diakibatkan lambatnya pertambahan jumlah produksi pedet. Untuk mengatasi hal ini, salah satu upaya pemerintah Indonesia adalah menggalakkan program Inseminasi Buatan (IB) (Rusdiana and Praharani, 2019). Akan tetapi, adanya tata laksana perkawinan yang kurang optimal, ditemuinya kejadian birahi tenang dan masalah deteksi estrus mengakibatkan penentuan waktu optimal IB tidak tepat (Tapohianong et al., 2014) yang berakibat pada kegagalan fertilisasi dan tidak terjadi kebuntingan (Ferraz et al., 2017).

Salah satu cara untuk mengontrol kinerja reproduksi ternak adalah dengan metode Sinkronisasi Estrus (SE) (Chao et al., 2008) menggunakan injeksi preparat hormon (Gordon, 2005; Senger, 2005). Metode ini bertujuan untuk mempermudah manajemen pemeliharaan ternak, pemeliharaan anak dan meningkatkan efisiensi reproduksi (Karikari et al., 2009; Wildeus, 2000). Adapun hormon yang lazim digunakan adalah prostaglandin $\mathrm{F} 2 \alpha$ (PGF2 $\alpha$ ) (Prastowo et al., 2011, 2010). Dijelaskan lebih lanjut bahwa metode ini merupakan salah satu jenis teknologi reproduksi (Kaya et al., 2018) yang dapat meningkatkan efisiensi reproduksi dalam hal peningkatan kualitas genetik (Lamb et al., 2010) dan populasi ternak dalam waktu yang singkat (Dogan et al., 2005).

Kelompok Tani Sri Mulyo merupakan kelompok peternak berkedudukan di Desa Pucang Miliran, Kecamatan Tulung, Kabupaten Klaten. Adapun bidang usaha yang digeluti kelompok tani ini adalah bidang pertanian tanaman pangan, peternakan sapi dan pengolahan pupuk. Sejalan dengan kebijakan pengembangan usaha pertanian dan peternakan di Kabupaten Klaten, kelompok tani ini telah mendapatkan beberapa program bantuan dalam bentuk hibah sapi PO betina berumur 2-3 tahun sebanyak 20 ekor. Terkhusus pada pengelolaan sapi PO betina, jumlah sapi bunting didapati masih rendah. Berdasar komunikasi awal dengan peternak di kelompok tani tersebut, diketahui bahwa penyebab rendahnya angka kebuntingan salah satunya adalah birahi yang tidak tampak sehingga peternak mengalami kesulitan penentuan waktu perkawinan yang tepat. Selain itu, keberadaan tenaga inseminator untuk IB, karena pertimbangan waktu dan jarak, menjadi permasalahan pula.
Berdasar permasalahan tersebut diatas, maka tujuan dari program pengabdian kepada masyarakat ini adalah untuk meningkatkan keberhasilan IB yang tercermin dari angka kebuntingan sapi, melalui pengamatan tandatanda estrus yang tepat. Untuk itu, penerapan sinkronisasi estrus yang dilanjutkan dengan IB dapat menjadi pilihan yang dilihat dari sisi efisiensi dan efektifitasnya. Diharapkan dari penerapan sinkronisasi estrus dan IB, maka jumlah sapi PO betina yang bunting dapat meningkat di kelompok tani Sri Mulyo. Selanjutnya, program sinkronisasi estrus ini juga diharapkan dapat berkelanjutan dan bisa diterapkan untuk meningkatkan pendapatan petani peternak.

\section{METODE}

Pelaksanaan program pengabdian kepada masyarakat ini dilakukan dalam durasi 15 bulan, pada medio tahun 2017 menggunakan 20 ekor sapi PO betina milik peternak di kelompok tani Sri Mulyo yang selanjutnya disebut kelompok tani mitra. Teknologi sinkronisasi estrus yang akan diterapkan untuk membantu menyelesaikan masalah mitra adalah metode yang telah diteliti dan dikembangkan oleh penulis yaitu penggunaan hormon PGF $2 \alpha$ untuk sinkronisasi estrus terbukti efektif untuk meningkatkan kinerja reproduksi ternak (Prastowo et al., 2011, 2010).

Program pengabdian ini dilakukan dalam 3 tahap, yaitu sosialisasi, pelaksanaan dan evaluasi keberhasilan program. Informasi dan kesepakatan tentang program SE disosialisasikan pada tahap pertama, dilanjutkan dengan pelaksanaan atau implementasi dilapangan. Implementasi program SE dilakukan seperti alur pada Gambar 1, yang dimulai dengan pemeriksaan organ reproduksi sapi. Hal ini menjadi dasar penentuan kondisi fisiologis untuk menentukan normal tidaknya organ reproduksi. Sapi betina dengan kondisi organ reproduksi yang memenuhi syarat selanjutnya disiapkan untuk memasuki tahapan SE sesuai dengan alur pada Gambar 2. Hormon PGF2 $\alpha$ diinjeksikan sesuai dosis berdasarkan bobot badan sapi dengan interval 11 hari. Setelah injeksi hormon yang kedua, 24-48 jam kemudian tanda-tanda estrus diamati yang diikuti dengan pelaksanaan IB oleh inseminator. Bersamaan dengan penyiapan sapi untuk program SE, sapi diberikan supplemen pakan konsentrat dan mineral dan selama proses pemeliharaan. 


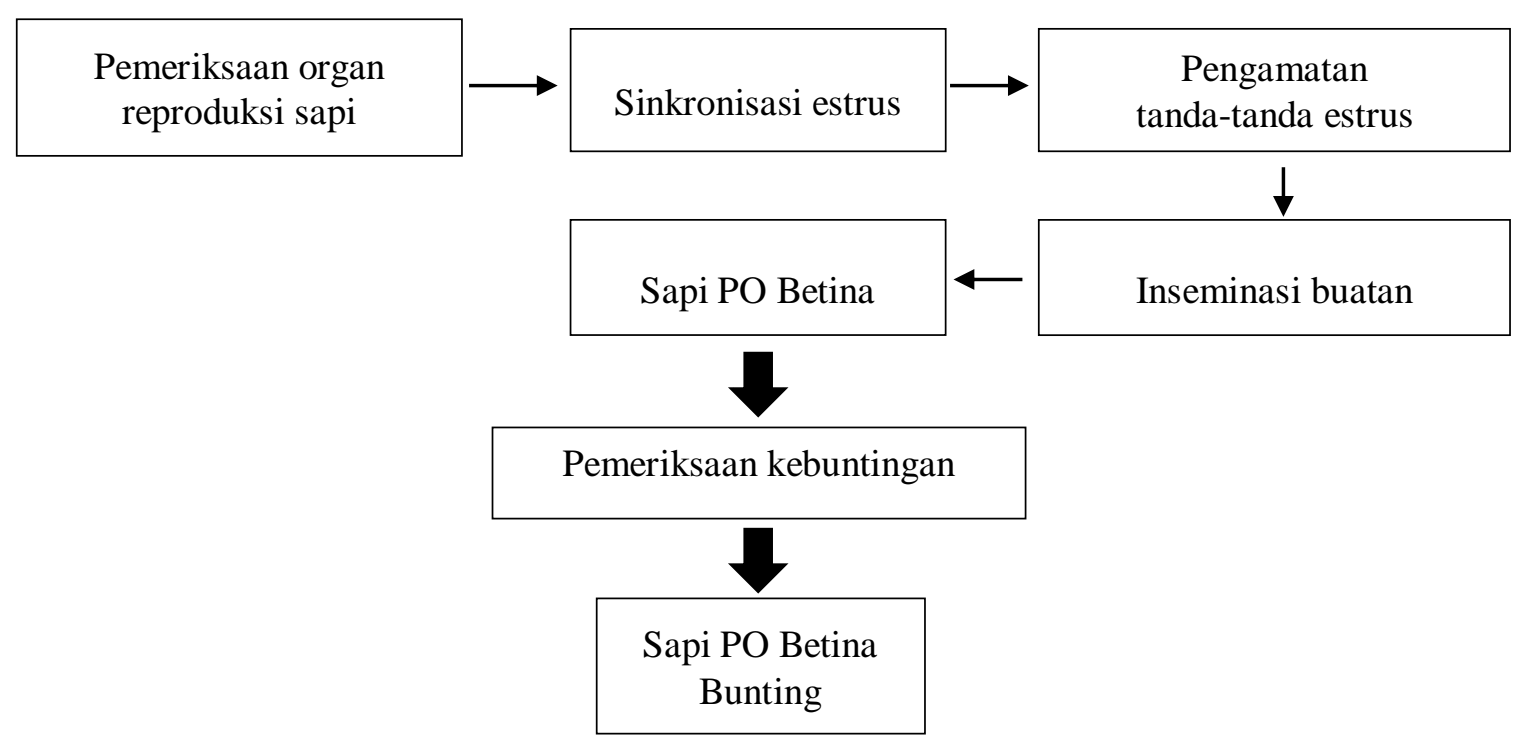

Gambar 1. Alur pelaksanaan proses sinkronisasi estrus

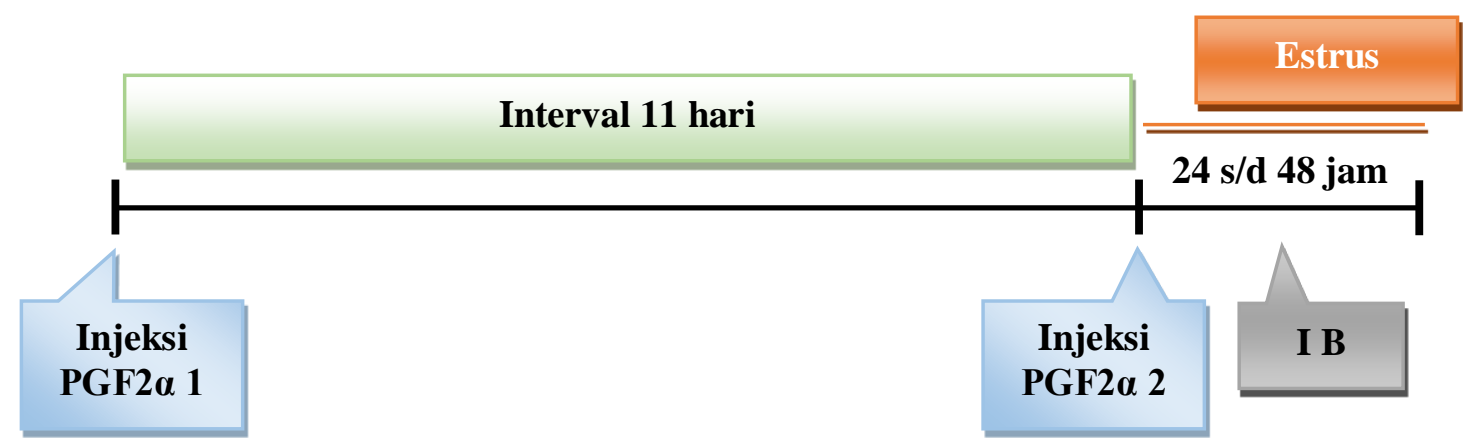

Gambar 2. Program sinkronisasi estrus dengan hormon PGF2 $\alpha$

Tujuan dari suplementasi ini adalah untuk memenuhi kebutuhan unsur nutrisi mikro sekaligus meningkatkan penyerapan nutrisi pakan untuk mendukung kinerja reproduksi yang optimal. Keberhasilan program SE dan IB akan dievaluasi pada hari ke 21 setelah IB dengan mengamati tanda-tanda estrus, dan pada hari ke 60 dengan melakukan pemeriksaan kebuntingan dengan metode palpasi rektal. Untuk ternak betina yang belum bunting, akan dikembalikan pada program SE berikutnya untuk dilakukan IB kembali pada siklus estrus berikutnya. Sementara ternak yang dinyatakan positif bunting, akan terus dipelihara sampai proses kelahiran terjadi. Selain evaluasi keberhasilan program SE pada ternak, evaluasi kegiatan pengabdian juga dilakukan bersama dengan para anggota kelompok tani mitra melalui pertemuan rutin sebagai bentuk diseminasi hasil.

\section{HASIL DAN PEMBAHASAN}

Sesuai dengan perencanaan, program pengabdian ini dibagi menjadi 3 tahap utama. Tahap 1 adalah tahap sosialisasi, tahap 2 adalah pelaksanaan kegiatan SE, dan pada tahap 3 adalah evaluasi hasil IB dengan melihat jumlah kebuntingan sapi. Tahap 1 dilakukan dengan mengadakan pertemuan dengan anggota kelompok tani mitra dan perwakilan pemerintah desa (Gambar 3). Dalam pertemuan tersebut, dilakukan pemaparan rencana program pengabdian, perencanaan pelaksaan program dan kontribusi yang dapat dilakukan oleh masing-masing pihak. Rencana pengabdian dipaparkan untuk memberikan gambaran secara menyeluruh tentang program peningkatan kinerja reproduksi sapi PO dengan menggunakan aplikasi sinkronisasi estrus. 

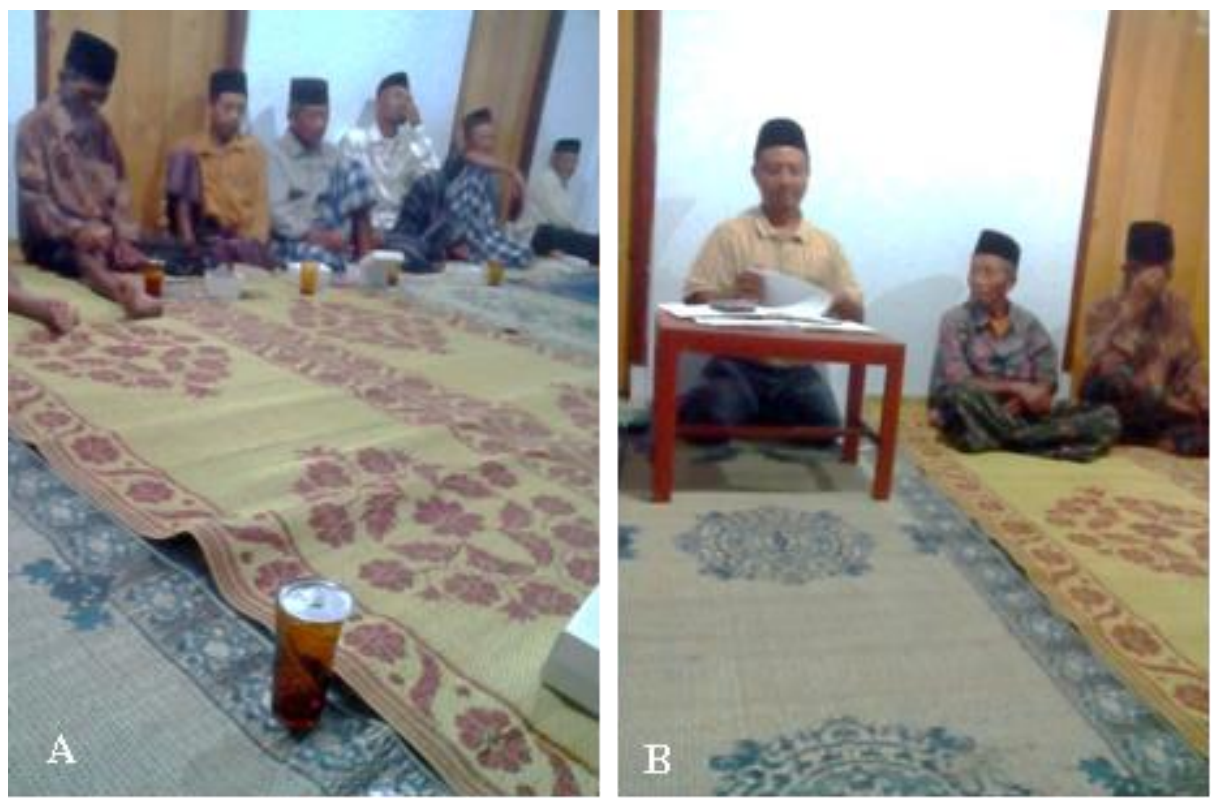

Gambar 3. Suasana pertemuan sosialasi program pengabdian dengan kelompok tani ternak mitra

(A), sambutan dari ketua kelompok ternak yang sekaligus sebagai perwakilan desa (B).

Sementara pelaksanaan program sinkronisasi estrus (Tahap 2) disampaikan seperti program pada Gambar 1 dan 2. Penentuan waktu pelaksanan, koordinasi dengan dokter hewan dan inseminator dari pemerintah Kabupaten Klaten yang bekerja di wilayah desa Pucang Miliran tempat mitra kelompok tani, sangat diperlukan untuk keberhasilan program.

Tahap 2 atau tahap pelaksanaan, dilakukan dengan alur seperti pada Gambar 1 . Hal pertama yang dilakukan adalah koordinasi dan pemeriksaan organ reproduksi dan kebuntingan dengan metode palpasi rektal (Gambar 4). Pemeriksaan ini dilakukan oleh dokter hewan dari Pemerintah Kabupaten Klaten yang bekerja di wilayah Kecamatan Tulung, dimana Desa Pucang Miliran tempat kelompok tani mitra berlokasi. Berdasar pemeriksaan kebuntingan, sapi PO di kelompok tani mitra dikelompokkan menjadi 3 kategori yaitu bunting, belum bunting sudah siap kawin dan belum bunting belum siap kawin. Hasil pemeriksaan organ reproduksi diperoleh sebanyak 12 ekor sapi belum bunting sudah siap kawin, sehingga siap untuk digunakan pada program SE, sedangkan 8 ekor lainnya, 4 ekor dalam kondisi bunting dan 4 ekor pada kondisi ovarium yang tidak optimal yang berarti belum bunting dan belum siap kawin. Selanjutnya, pada sapi yang belum bunting sudah siap kawin dilakukan program sinkronisasi estrus seperti pada Gambar 2. Hormon PGF2 $\alpha$ disuntikan secara intramuscular (Gambar 5) oleh dokter hewan dan diulang 11 hari kemudian. Sementara pada sapi yang belum bunting belum siap kawin, dilakukan pemeliharaan oleh peternak dengan tambahan pakan konsentrat dan diharapkan setelah kurang lebih 2 bulan sudah siap untuk dilakukan program sinkronisasi estrus.

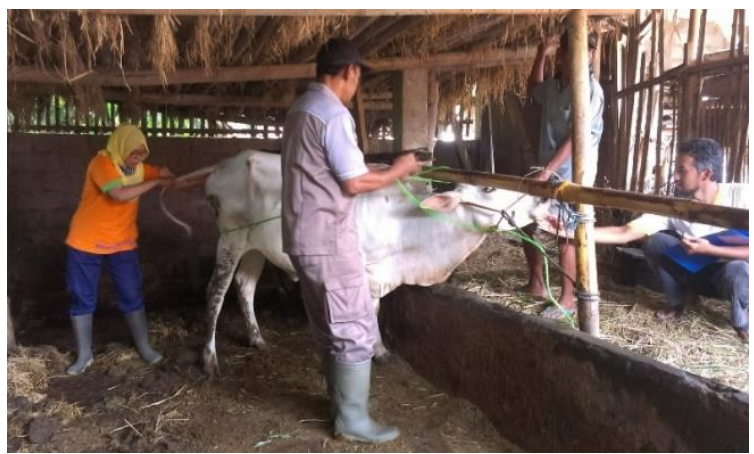

Gambar 4. Pemeriksaan organ reproduksi dan kebuntingan dengan metode palpasi rektal

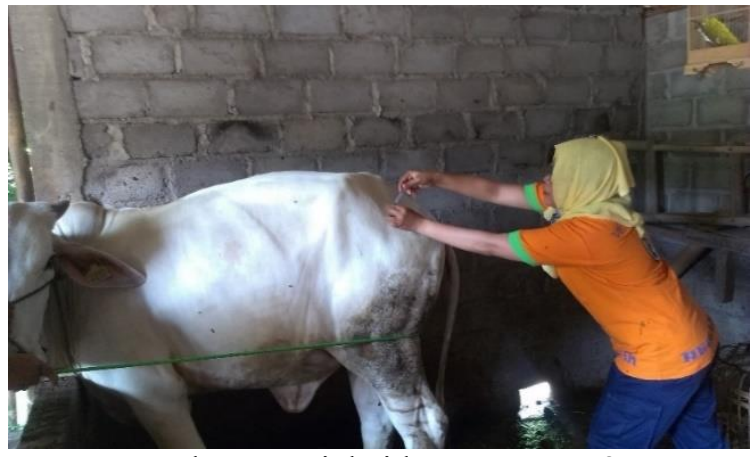

Gambar 5. Injeksi hormon PGF2 $\alpha$

Prostaglandin F2 $\alpha$ (PGF2 $\alpha$ ) merupakan hormon yang diproduksi oleh uterus sebagai akibat dari stimulasi oxytocin pada saat tidak 
terjadi implantasi embryo (Senger, 2005). Terjadinya estrus setelah pemberian hormon PGF2 $\alpha$ disebabkan karena lisisnya CL pada ovarium sehingga kadar progesteron menurun dan selanjutnya memberikan umpan balik positif ke hiphotalamus-hipofisa untuk melepaskan Follicle Stimulating Hormone (FSH). Sejalan dengan dikeluarkannya hormon $\mathrm{FSH}$, folikel pada ovarium akan berkembang yang dibarengi dengan akumulasi produksi hormon estrogen yang mengakibatkan ternak betina menampakkan tanda-tanda estrus (Hafez, 2000; Senger, 2005; Toelihere, 1993). Tanda-tanda estrus pada sapi yang disinkronisasi, diamati dengan melihat perubahan kondisi vulva dan perilaku ternak (Allrich, 1993; Rao et al., 2013) yang selama ini sudah diketahui oleh peternak. Secara normal, estrus akan terjadi 24-48 setelah injeksi PGF2 $\alpha$, dengan demikian inseminasi baik secara alamiah atau buatan dapat dilakukan 1012 jam setelah tanda-tanda estrus terlihat.

Hasil pengamatan oleh peternak, didapatkan 10 ekor sapi menunjukan tanda-tanda estrus, sedangkan 2 ekor lainnya terlewat pengamatannya. Selanjutnya, sapi-sapi yang mengalami estrus diinseminasi oleh inseminator menggunakan semen beku (Gambar 6A, 6B), 10-12 jam setelah tanda-tanda estrus teramati oleh peternak. Semen beku yang digunakan merupakan produksi Balai Inseminasi Buatan, volume $0.25 \mathrm{ml}$ dengan pengencer Tris Citrat Kuning Telur, dan dibekukan pada Nitrogen cair dengan suhu $-196^{\circ} \mathrm{C}$. Sebagai bentuk pencatatan, inseminator selanjutnya mencatat waktu inseminasi pada kartu inseminasi (Gambar 7) yang akan digunakan nantinya dalam perhitungan dan proses evaluasi keberhasilan inseminasi buatan dengan mendeteksi kebuntingan.

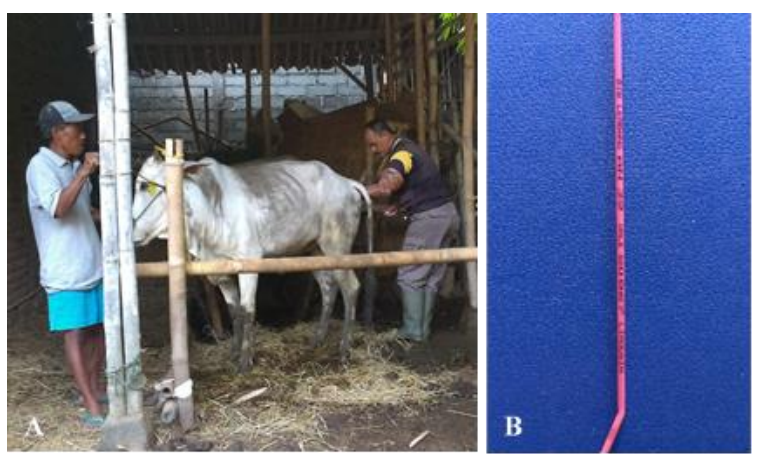

Gambar 6. Inseminasi buatan (A), semen beku yang digunakan (B).

Untuk meningkatkan kecukupan nutrisi, pakan tambahan berupa mineral plus probiotik dan konsentrat juga diberikan pada sapi-sapi yang dipelihara oleh kelompok ternak mitra, baik yang digunakan dalam program SE atau tidak.

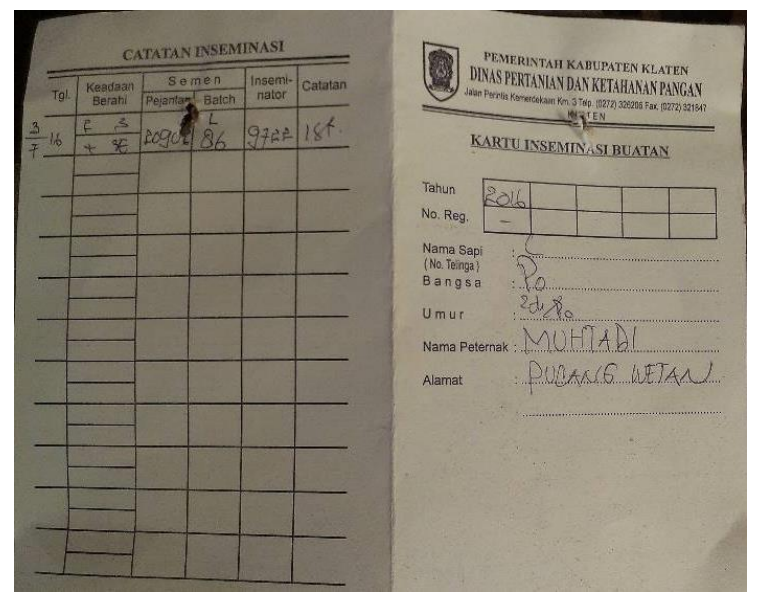

Gambar 7. Kartu inseminasi buatan

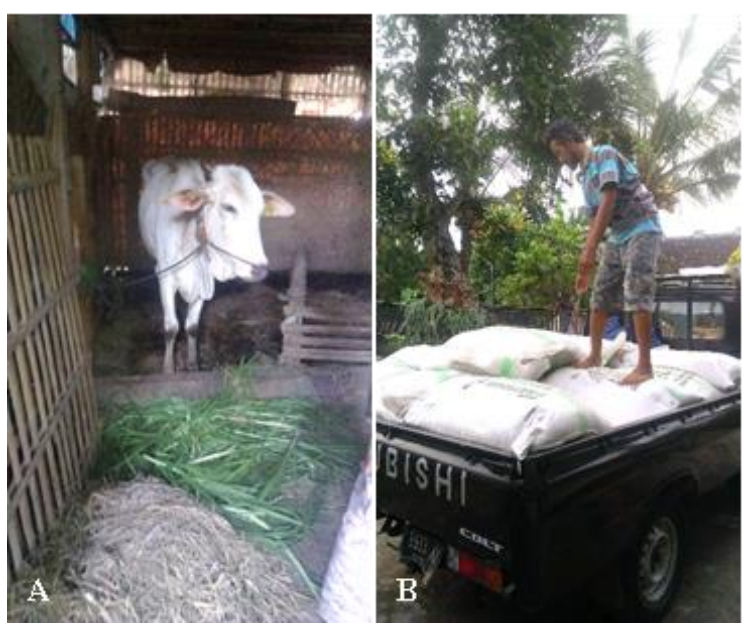

Gambar 8. Pakan ternak dikelompok tani Sri Mulyo (A), tambahan konsentrat untuk perbaikan pakan (B)

Hal ini dilakukan karena peternak di kelompok ternak mitra, hanya memberikan jerami dan hijauan sebagai pakan utama sapi (Gambar 8A, 8B). Hal demikian dapat berakibat pada ketersediaan nutrisi yang selanjutnya berimbas pada fungsi pertumbuhan dan reproduksi ternak yang terhambat (Bindari et al., 2013; Roche, 2006). Evaluasi program sinkronisasi estrus dilakukan dengan mengamati tampilan estrus sapi PO dalam program SE. Berdasar pengamatan, diketahui bahwa semua sapi PO yang mendapat suntikan hormon PGF2 $\alpha$, menunjukkan tanda-tanda estrus. Adapun tanda yang teramati adalah perubahan warna vulva dan tingkah laku. Selanjutnya, setelah tanda-tanda terlihat, IB dilakukan oleh inseminator terdekat menggunakan semen beku. 
Program evaluasi keberhasilan IB (Tahap 3) dilakukan dengan mengamati tanda-tanda estrus sapi PO pada hari ke 21 setelah IB. Diasumsikan bahwa sapi yang tidak kembali estrus mengalami kebuntingan. Untuk lebih memastikan kebuntingan, maka palpasi rektal dilakukan pada hari ke 60 setelah IB. Hasil evaluasi kebuntingan ditemukan sebanyak 6 ekor sapi tidak menunjukan tanda-tanda estrus pada hari ke 21 setelah IB, kemudian konfirmasi kebuntingan pada hari ke 60 didapatkan 4 ekor sapi dinyatakan positif bunting. Hasil kelahiran pedet sejumlah 4 ekor, dapat dilihat pada Gambar 9 berupa pedet dari pejantan sapi Limousin (Gambar 9A) dan pedet dari pejantan sapi Simmental (Gambar 9B).
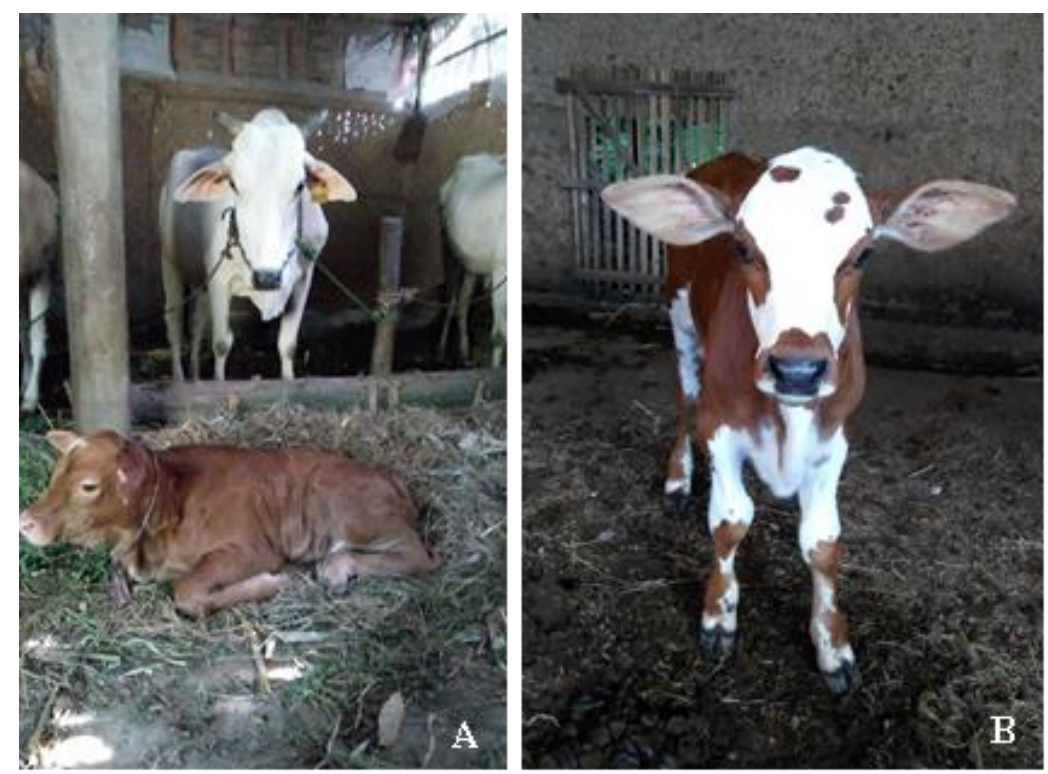

Gambar 9. Pedet hasil IB menggunakan semen sapi Limousin (A) dan Simental (B)

\section{KESIMPULAN}

Berdasarkan hasil evaluasi pelaksanaan pengabdian di kelompok tani ternak Sri Mulyo, dapat disimpulkan bahwa program SE dapat meningkatkan keberhasilan IB yang tercermin dari jumlah kebuntingan sapi, melalui pengamatan tanda-tanda estrus yang tepat. Untuk menjaga keberlanjutan program implementasi SE di kelompok tani ternak maka persiapan peternak dan tenaga ahli dalam arti tenaga inseminator dan pemeriksa kebuntingan dapat menjadi tindak lanjut setelah program ini. Selain itu, karena proses reproduksi sangat erat kaitannya dengan pakan maka pemberian pakan tambahan berupa konsentrat dapat dilakukan untuk meningkatkan produktivitas ternak

\section{DAFTAR PUSTAKA}

Allrich, R.D., 1993. Estrous behavior and detection in cattle. Veterinary Clinics of North America: Food Animal Practice, 9, 249-262. https://doi.org/10.1016/S07490720(15)30644-7

Astuti, M., 2004. Potensi dan Keragaman
Sumberdaya Genetik Sapi Peranakan Ongole (PO). Wartazoa, 14, 30-39.

Bindari, Y.R., Shrestha, S., Shrestha, N., Gaire, T.N., 2013. Effects of nutrition on reproduction- A review. Advances in Applied Science Research, 4, 421-429.

Chao, L., Takayama, K., Nakanishi, Y., Hamana, K., Takagi, M., Kubota, C., Kojima, T., 2008. Luteal lifespan and fertility after estrus synchronization in goats. Journal of Veterinary Science, 9, 95-101.

Dogan, I., Nur, Z., Gunay, U., Sagirkaya, H., Soylu, K., Sonmez, C., 2005. Estrus synchronization during the natural breeding season in Anatolian black does. Veterinary Medicine Czech, 50, 33-38.

Ferraz, P.A., Loiola, M.V.G., Rodrigues, A.S., Lima, M.C.C., de Bittencourt, T.C.B. dos S.C., Ribeiro Filho, A. de L., 2017. The effect of the intensity of estrus expression on the follicular diameter and fertility of nellore cows managed under a FTAI program. Ciência Animal Brasileira, 18, 19. https://doi.org/10.1590/1089-6891v18e37643 
Gordon, I., 2005. Reproductive Technologies in Farm Animals. CABI Publishing. UK.

Hafez, E.S.E., 2000. Reproduction in Farm Animals. $6^{\text {th }} E d$. Lea and Febiger, Philadelphia.

Hartati, Sumadi, Hartatik, T., 2010. Identifikasi karakteristik genetik sapi peranakan ongole di peternakan rakyat. Buletin Peternakan, 33, 64-73.

Inounu, I., 2017. Supported Science and Reproductive Technology to Achieve Cows Pregnancy Program Succesfully. Wartazoa, 27, 23-34. https://doi.org/10.14334/wartazoa.v27i1.1 368

Karikari, P., Blasu, E., Osafo, E., 2009. Reproductive Response of West African Dwarf Does to Prostaglandin Administration. World Applied Science Journal, 6, 542-545.

Kaya, A., Günes, E., Memili, E., 2018. Application of reproductive biotechnologies for sustainable production of livestock in Turkey. Turkish Journal of Veterinay and Animal Science. 42, 143151. https://doi.org/10.3906/vet-1706-66

Kusuma, S.B., Ngadiyono, N., Sumadi, S., 2017. Estimasi Dinamika Populasi Dan Penampilan Reproduksi Sapi Peranakan Ongole Di Kabupaten Kebumen Provinsi Jawa Tengah. Buletin Peternakan, 41, 230. https://doi.org/10.21059/buletinpeternak.v 41i3.13618

Lamb, G.C., Smith, M.F., Perry, G.A., Atkins, J.A., Risley, M.E., Busch, D.C., Patterson, D.J., 2010. Reproductive endocrinology and hormonal control of the estrous cycle. The Bovine Practicioner, 44, 18-26.

Prastowo, S., Ratriyanto, A., Sudiyono, Sunarto, 2010. Kinerja Reproduksi Kambing Peranakan Ettawa (PE) yang Diberi Pakan Suplemen Urea Molases Mineral Anti Parasit Blok (UMMAT Blok) dalam Program Inseminasi Buatan Berbasis Sinkronisasi Estrus. Laporan Penelitian DIPA BLU FP UNS Tahun Anggaran 2010. Jurusan Peternakan, Fakultas Pertanian, Universitas Sebelas Maret.Surakarta.

Prastowo, S., Widyas, N., Sunarto, 2011. Efektivitas Dosis dan Lokasi Injeksi Hormon PGF $2 \alpha$ Terhadap Tampilan Estrus dan Keberhasilan Inseminasi Buatan pada
Kambing Peranakan Ettawa dalam Program Sinkronisasi Estrus. Laporan Penelitian Dana DIPA BLU FP UNS Tahun Anggaran 2011. Jurusan Peternakan, Fakultas Pertanian, Universitas Sebelas Maret. Surakarta.

Rao, T.K.S., Kumar, N., Kumar, P., Chaurasia, S., Patel, N.B., 2013. Heat detection techniques in cattle and buffalo. Veterinary World, 6, 363-369. https://doi.org/10.5455/vetworld.2013.363 $-369$

Roche, J.F., 2006. The effect of nutritional management of the dairy cow on reproductive efficiency. Animal Reproduction Science, 96, 282-296. https://doi.org/10.1016/j.anireprosci.2006. 08.007

Rusdiana, S., Praharani, L., 2019. Pengembangan Peternakan Rakyat Sapi Potong: Kebijakan Swasembada Daging Sapi Dan Kelayakan Usaha Ternak. Forum Penelitian Agro Ekonomi, 36, 97-116. https://doi.org/10.21082/fae.v36n2.2018.9 $7-116$

Senger, P., 2005. Pathway to Pregnancy and Parturition, $2^{\text {nd }} E d$. Pullman, Washington.

Setiawan, D., 2018. Artificial Insemination of Beef Cattle UPSUS SIWAB Program Based on the Calculation of Non-Return Rate, Service Per Conception and Calving Rate In The North Kayong Regency. The International Journal of Tropical Veterinary and Biomedical Research, 3, 710.

https://doi.org/10.21157/ijtvbr.v3i1.11339

Tapohianong, T., Agung, B., Erif, M., 2014. Tinjauan hasil inseminasi buatan berdasarkan anestrus pasca inseminasi pada peternakan rakyat sapi Bali di Kabupaten Sikka Nusa Tenggara Timur. Sains Veteriner. 32, 46-54.

Tilman, D., Balzer, C., Hill, J., Befort, B.L., 2011. Global food demand and the sustainable intensification of agriculture. PNAS, 108, 20260-20264. https://doi.org/10.1073/pnas.1116437108

Toelihere, M.R., 1993. Fisiologi Reproduksi pada Ternak. Angkasa, Bandung.

Wildeus, S., 2000. Current concepts in synchronization of estrus: Sheep and goats. Journal of Animal Science, 77, 1-14. 